\title{
DUE DILIGENCE: \\ ESSENCE AND POSSIBLE PROSPECTS OF DEVELOPMENT
}

\author{
Oleksandr Novikov', Maryna Dubinina², Vitalii Kuzoma ${ }^{3}$ \\ Mykolayiv National Agrarian University, Ukraine
}

\begin{abstract}
The subject of the study is a set of theoretical, methodological principles for the implementation of the due diligence procedure as an audit service in Ukraine. The methodological basis of the study is general scientific and special methods of cognition. There was clarified the concept of due diligence as audit service using the methods of theoretical generalization, comparison of the accounting, and due diligence by the method of comparison. The peculiarities, current problems, and obstacles of the development of due diligence in Ukraine are determined with the help of the abstract-logical method and structural-logical analysis. The objective of the study is to consider the essence of the concept of due diligence as an audit service, to identify the main obstacles, and to formulate prospects for its development in Ukraine. In Ukraine, the due diligence is equated to a legal audit. However, the concept of the legal audit is much narrower and characterizes the legal expertise of the company's compliance with the requirements of the law. As a result of the study, it was found that due diligence is a procedure for conducting a comprehensive examination of an investment agreement in the framework of making a decision on effective capital investment by minimizing risks in order to preserve this capital and its potential future increase. It is proved that it is expedient to involve specialists of different professional orientations such as appraisers, lawyers, financiers, project managers, and crisis managers for the implementation of due diligence. The task team can include economists, engineers, security specialists and other experts. Varieties of due diligence are considered and its differences from the traditional audit are determined. It is substantiated that when improving the method of due diligence, it is necessary to understand its difference with the audit. The role of the due diligence procedure in the conclusion of enterprise sales contract is determined, namely, the reduction of existing investment risks. The "success" of the agreements or their "failure" is explained by the nature of the emerging synergy, and also by the fact that enough time was spent on conducting the due diligence. The sequence and structure of the due diligence process, as an audit service, were defined, outlining the content of its individual stages and works, which gave an opportunity to develop the algorithm of the due diligence procedure. It is established that due diligence is a rather new phenomenon for Ukraine, and audit and specialized companies are only at the beginning of the path in this direction. In order to develop this type of services, it was suggested that auditors and specialized companies expand the range of services in the direction of due diligence and the corresponding procedure for its conduct. The cooperation of Ukrainian professional organizations with foreign professional organizations should be developed in order to provide specialists with the possibility to obtain international certificates, as well as to involve audit, legal, and consulting companies in the process of vocational training in the direction of due diligence. The conclusion of the study. Thus, due diligence includes a set of measures to conduct a comprehensive examination of an investment agreement within the framework of making a decision on effective capital investment, which involves significant economic risks. The need for due diligence is due primarily to the fact that in today's market relations, the requirements of investors, banking institutions, and buyers are increased to the transparency of information about the object of investment, lending or purchase. Due diligence as a research tool allows you to get a realistic assessment of your business, to determine the financial position and business development trends, as a result of obtaining information that will have a qualitative impact on effective management decisions.
\end{abstract}

Key words: due diligence, audit, expertise, capital, investment agreement.

JEL Classification: E22, G32, M20, M40, M49

\footnotetext{
Corresponding author:

${ }^{1}$ Department of World Agriculture and Foreign-Economic Activity, Mykolayiv National Agrarian University.

E-mail: novikov@mnau.edu.ua

${ }^{2}$ Department of Accounting and Taxation, Mykolayiv National Agrarian University.

E-mail: dubinina@mnau.edu.ua

${ }^{3}$ Department of Accounting and Taxation, Mykolayiv National Agrarian University.

E-mail:kuzyoma@mnau.edu.ua
} 


\section{Introduction}

Each enterprise interested in attracting external sources to finance its development needs to have a sufficient level of investment attractiveness, given the high competition of objects of real investments in the market of investment resources, especially in the current conditions of limited financial resources for the Ukrainian economy. Therefore, an assessment of the current level of investment attractiveness is analytically determined while minimizing the risks of making an erroneous decision, which is necessary for both sides of the process. Firstly, the management of the enterprise needs it for a well-defined definition of the vector for further development of the company in order to improve its investment image. Secondly, investors need to assess the status of potential enterprises-candidates, the prospects for their development, taking into account all the attendant factors that are important for them in order to make a decision on the choice of the recipient enterprise.

Carrying out the procedure of due diligence will help to create a complete picture of the actual financial condition of the enterprise and of all the risks that may have a negative impact.

Foreign scientists: L. Gilman, J. Camp, J. Bower, S. Foster Reed, M. Hudson, and others studied the peculiarities of conducting the due diligence procedure. Among domestic scientists, V. Lykhovchuk, I. Tkachuk, O. Hlynskyi, A. Halkevych, and others scientists and researchers-economists devoted their works to the procedure of due diligence. However, due to the insignificant number of conducted due diligence procedures in Ukraine, domestic scientists mainly use foreign experience in their studies.

The subject of the study is a set of theoretical, methodological principles for the implementation of the due diligence procedure as an audit service in Ukraine.

The objective of the study is to consider the essence of the concept of due diligence as an audit service, to identify the main obstacles and to formulate prospects for its development in Ukraine.

To achieve the objective, the following tasks are foreseen:

- to study theoretical and practical approaches to define the concept of due diligence in order to clarify it; - to carry out the classification of due diligence in order to identify specific directions for its conduct;

- to determine the place of the due diligence procedure among audit services in order to distinguish the basic professional standard of audit as the basis for the acceptance of the task, implementation and reporting; - to construct an algorithm for the implementation of the due diligence procedure;

- to identify peculiarities, current problems, and obstacles to the development of due diligence in Ukraine.
The general scientific and specific methods of scientific knowledge are used: theoretical generalization and grouping, comparison, abstract-logical, structurallogical analysis, classification, systematization, causal relationship.

\section{The essence of the concept of due diligence}

At the present stage of development of the economy, the actualization of investment activity as an effective mechanism of enterprise development is an important issue. In foreign practice, the accompanying procedure for the investment process is the implementation of due diligence.

Translated from English, the term "due diligence" has the meaning of "ensuring due diligence". For the first time, this concept appears in the US Securities Act of 1933 (SEC). The due diligence was understood then as the method of disclosing information by the broker to the investor about the company whose shares were sold on the stock exchange. Later a community of brokers was formed, which conducted a procedure on a permanent basis for the sale of securities. Nevertheless, the term "due diligence" was not clearly defined, because of the impossibility of establishing common requirements for the task for different companies (Spedding, 2009).

The due diligence acquired a wide range of use in the banking sector in the 1970s. At that time, modern standards for due diligence were developed and implemented in Switzerland. The goal of introducing such standards was the desire to avoid rigid government regulation and control over the banking sector. In 1977, Swiss banks signed the Agreement on the Swiss banks' code of conduct with regard to the exercise of due diligence, which defined a unified methodology for obtaining and storing data about clients wishing to open accounts and continue to be served at these banking institutions (Dunant, 1988).

In the 1990s, the integration of enterprises was vital for stability in a dynamic and uncertain environment in the United States. In such circumstances, it is necessary to obtain information for making investment decisions. But at that time, buyers were not in a position to implement the due diligence procedure, because it required time and access to the required information. The spread of this procedure was due to the SarbanesOxley Act of 2002, which created a new mode of control and regulation of financial activities, and there were significant changes in the management and disclosure requirements of the issuer. Subsequently, in the process of mergers and acquisitions, the buyer was given full and free access to information during the due diligence (Nigh John, 2004).

It is thanks to these changes that the due diligence procedure came from the banking sector to modern business. It represents a stage of the investment process, which includes a comprehensive analysis of the 
company's activities from the point of view of financial analysts, auditors, and lawyers.

To date, there is no scientifically substantiated definition of the concept of due diligence which, in our opinion, is due to the peculiarities of carrying out this procedure in accordance with each task.

The study of the above-mentioned approaches to the interpretation of the concept of due diligence has enabled us to clarify this concept. Thus, under the due diligence, we propose to understand the procedure for carrying out a comprehensive examination of an investment agreement in the framework of making a decision on effective investment of capital by minimizing risks in order to preserve this capital and its potential future increase.

The classic classification of due diligence is presented in Fig. 1.

Although the Due Diligence procedure involves undertaking a comprehensive analysis of the company's activity, sometimes the concept of due diligence is understood as a perfect analysis and study of only a separate component of the company's activities. This is due to the division of the procedure into species, according to the key direction of the implementation.

We affirm that the main purpose of the due diligence procedure is to provide the investor with a complete picture of the real financial situation of the investment object and minimize the existing risks of transactions when making a decision on investing capital.

\section{The main differences between forensic audit and audit}

In Ukraine, due diligence is at the stage of development. In spite of the growing demand for this service, due to the expansion of domestic enterprises to international capital markets and current mergers and acquisitions, due diligence has significant problems in its implementation in our country.
To date, in the Law of Ukraine "On Auditing" a comprehensive examination of the object of investment "due diligence" (as a form of services) is not officially envisaged. Despite the generally accepted world principles of due diligence, they are not standardized in our country. In addition, there is almost no scientific literature on this issue.

Studying the procedure of due diligence, it can be associated with an audit. However, it is not appropriate to identify the categories of "audit" and "due diligence", since "due diligence" does not offer an opinion on financial statements, as audit does. The main purpose of this check is to collect information about the investment object and conduct procedures for assessing the potential risks associated with it. Table 1 summarizes the main differences between the audit and the procedure of due diligence.

At the same time, in the absence of the regulatory framework and regulation of the implementation of the due diligence procedure by the state, the demand for it exists and the customer expects to receive a full and substantive report on the results of a quality examination. That is why the most often executives of such expertise are auditing firms.

The due diligence procedure can be considered as an assurance engagement. In accordance with International Standard on Assurance Engagements (ISAE) "Assurance Engagements Other Than Audits or Reviews of Historical Financial Information" (hereinafter referred to as the ISAE 3000), the assurance engagements include both verification tasks (where another party than a practitioner measures or evaluates the subject of the task with respect to criteria), and direct tasks (where the practitioner measures or evaluates the subject of the task with respect to the criteria).

When performing the procedure of due diligence, it is advisable to follow the rules established by the International Standards on Quality Control, Auditing, Assurance and Related Services (hereinafter ISA).

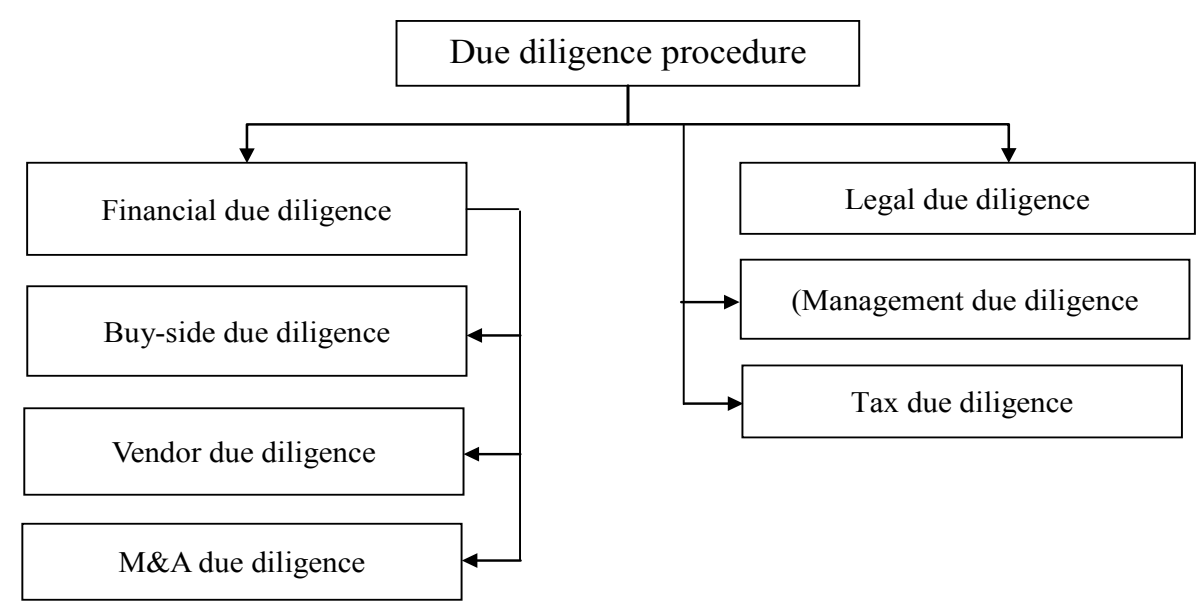

Fig. 1. Classification of Due Diligence [summarized by the authors according to the sources (Kasych, 2015, Byrka, 2013)] 
Table 1

Comparative Characteristics of Audit and Due Diligence Procedure

\begin{tabular}{|c|l|l|l|}
\hline № & \multicolumn{1}{|c|}{ Criteria for comparison } & \multicolumn{1}{c|}{ Audit } & \multicolumn{1}{c|}{ Due diligence } \\
\hline 1 & Objective & $\begin{array}{l}\text { Giving the auditor an } \\
\text { opportunity to express an } \\
\text { opinion on whether the financial } \\
\text { statements have been prepared } \\
\text { in all material respects in } \\
\text { accordance with the applicable } \\
\text { financial reporting framework }\end{array}$ & $\begin{array}{l}\text { Formation of a complete picture of the real financial position } \\
\text { of the company, the physical availability of assets, all current } \\
\text { and potential liabilities, as well as all tax, financial, and } \\
\text { investment issues that may significantly impair the financial } \\
\text { position of the company in the foreseeable future. }\end{array}$ \\
\hline 2 & Subjects & $\begin{array}{l}\text { The presence of requirements for } \\
\text { mandatory implementation in } \\
\text { cases established by law }\end{array}$ & \multicolumn{1}{c|}{ Yes } \\
\hline 4 & Reporting & $\begin{array}{l}\text { Experts in the field of audit, accounting, analysis, finance, law, } \\
\text { having experience of due diligence. }\end{array}$ & No \\
\hline
\end{tabular}

* generalized by the author (Kasych, 2015, Nazarenko, 2011)

On the other hand, the procedure of due diligence can be viewed as a coordinated procedure for financial information and one can be guided by the rules and regulations set forth in the International Standard on Related Services 4000 "Engagements to Perform Agreed-Upon Procedures Regarding Financial Information" (hereinafter referred to as the ISRS 4400).

We believe that due diligence should be considered as an accompanying audit service, since this audit involves the collection, preparation, and analysis of information and, according to ISA, related services include agreed procedures and compilation of information.

ISRS 4400 defines the purpose of the task of the agreed procedures, as the implementation of those audit procedures agreed by the auditor, the entity and any relevant third parties, as well as reporting on the actual results.

The audit firm only provides a report on the actual results of the agreed procedures (due diligence) and does not express confidence in the financial statements. But the users of the report, in turn, assess by themselves the procedures and results given in the report and make their own conclusions on the basis of the work of the performer.

Understanding the nature of the due diligence procedure and its legislative and normative background is just as important as the definition of the purpose and stages of the due diligence procedure. This determines the success of its implementation in the future, and hence the success of the investment agreement.

\section{Prospects for development in Ukraine}

Based on the classical understanding of due diligence, users of the information obtained as a result of the task are potential investors willing to confirm the return on their investment, or the acquirer, who considers it necessary to establish the degree of existing risk and find out the real value of the estimated enterprise. But, given the nature of the "due diligence" and the results obtained during the execution of the task, users of this service may also be banking institutions willing to investigate the financial condition of the borrower and the owners of the enterprise, with the aim of disclosing information about the activities of the company for evaluation profitability of invested investments. This emphasizes the significance of the "due diligence" from the point of view of elimination and the maximum reduction of existing business risks and destructive factors of the environment, and stipulates the need for a qualitative task that should be based on the appropriate methodology.

There is no doubt that one of the topical issues of the organization of the audit is the sequence of inspections, that is, the definition of stages of the audit.

We have determined an algorithm for the implementation of the due diligence procedure. Of course, the proposed scheme is not inviolable. It can be influenced by the approach to planning (sequential or parallel), the structure of the audit firm and the particulars of the entity under audit. The algorithm consists of the following steps: determining the scope of verification and cost of services; compiling a list of questions and necessary documents; carrying out of the inspection; drawing up a report; presentation of the report to the customer.

The problem of implementing due diligence is to choose a specific practical task, and there is no task for implementing due diligence, which is similar to another. However, this process requires a kind of modification of the forms and methods to ensure the effective operation of modern enterprises. The substantiation of the relevance and peculiarities of the implementation of due diligence is that it will contribute to maintaining a high level of quality of audit services in a full-scale European integration. 
For each individual enterprise, in the context of the due diligence procedure, a separate methodology should be developed to determine the continuity principle, which would cover all the features of the industry and the enterprise as a whole. Nevertheless, in our opinion, it is possible to identify key validation procedures that would be universal and subject only to individual adjustments. These procedures include:

- analysis of the data obtained at the preparatory stage concerning the industry, its structure, its staff, supply markets and markets, the price policy of the enterprise, etc. in order to form the idea of the possibility of continuous activity of the enterprise;

- analysis of the main indicators of the efficiency of the enterprise, trends in their changes compared with the current state;

- verification of conformity of financial statements to the current legislation;

- research of the accounting system and internal control;

- analysis of cash flows expected in the coming reporting periods, assessment of their level of adequacy to ensure uninterrupted activity;

- research of the "dependence" of the enterprise on financial institutions (banks, credit unions, etc.), the ratio of borrowed capital and equity;

- assessment of the provision of the company with the necessary personnel for normal operation (production, administrative personnel, other specialists);

- verification of credit history, the presence of lawsuits, violations of legislation (fines, sanctions, etc.) and the negative consequences of these events;

- consideration of possibilities of enterprise development, opening of new directions of activity or expansion of the client base and availability of concluded contracts with contractors;

- final formation of the idea of an enterprise's ability to conduct continuous activities (Moskal, 2014).

\section{Conclusions}

In modern conditions in Ukraine, the features of the procedure of due diligence have not been fully investigated and identified, and there is also the lack of practical implementation of due diligence in Ukrainian enterprises. Thanks to the study of foreign information sources and their practical experience, we have clarified the definition of the concept of "due diligence". So, under "due diligence" we propose to understand the procedure for conducting a comprehensive examination of the investment agreement within the framework of making a decision on effective capital investment, by minimizing risks, in order to preserve this capital and potentially increase it in the future. According to the results of the study, we maintain that there is currently no regulatory framework that would govern the implementation of the due diligence procedure.

In audit practice, it is quite logical to consider the procedure of due diligence as an audit service, namely, services that accompany the audit, and one should be guided by the standards established by the ISRS 4400 . The success of the due diligence procedure is influenced by a number of factors, including the purpose of the procedure, terms of its implementation, the composition of the working group, etc., and that is why the procedural tool for the adoption of the due diligence task requires a detailed study and definition of all existing aspects.

It is determined that the main purpose of the due diligence procedure is the formation of the investor's full understanding of the real financial condition of the investment object and minimization of the existing risks of transactions when making a decision on investing capital.

The sequence and structure of the process of due diligence, as an audit service for describing the content of its individual stages and works, have been developed, and it has made it possible to develop an algorithm for conducting a due diligence procedure.

Thus, due diligence is currently a very relevant procedure. Necessity is primarily due to the fact that in modern market relations, the requirements of investors, banking institutions, and buyers to the transparency of information about the object of investment, credit or purchase increase. Due diligence, as a research tool, allows you to get a real assessment of the business, determine the financial situation and development trends of the enterprise, and as a result receive information that will have a qualitative impact on the adoption of effective management decisions.

\section{References:}

Spedding L. S. (2009) The due diligence handbook. Corporate governance, risk management and business planning. CIMA Publishing, p. 709.

Dunant O. (1988) Swiss Bank Secrecy: It's Limits Under Swiss and International Laws, Case Western Reserve Journal of International Law, vol. 20, pp. 541-575.

Nigh John O. (2004) Due diligence under Sarbanes-Oxley, Emphasis, vol. 1, pp. 2-5.

Silichieva N. Ye. (2011) Sutnist due diligencei mozhlyvi perspektyvy rozvytku v Ukraini [Essence of due diligence and possible prospects for development in Ukraine], Ekonomichnyi prostir (Economic space), vol. 45, pp. $288-296$.

Kasych A. O. (2015) Diu Dilidzhens yak kliuchovyi instrument analizu dotsilnosti investuvannia [Due diligence as a key tool for analyzing the feasibility of investing], Oblik $i$ finansy (Accounting and finances), vol. 4 (70), pp. 92-97. 
Byrka M. I. (2013) Zastosuvannia protsedury «diu-dilidzhens» v protsesi zaluchennia priamykh inozemnykh investytsii na pidpryiemstva [Application of the procedure of due diligence in the process of attracting foreign direct investment in enterprises], Biznes inform (Business inform), vol. 1, pp. 81-85.

Nazarenko I. M. (2011) Diu dilidzhens: sutnist, pryznachennia ta poslidovnist provedennia [Due diligence: the essence, purpose and sequence of the implementation], Naukovi pratsi Kirovohradskoho natsionalnoho tekhnichnoho universytetu. Ekonomichni nauky (Scientific works of Kirovohrad National Technical University. Economic sciences), vol. 20, pp. 360-366.

Moskal N. V. (2014) Suchasni aspekty formuvannia zahalnoi stratehii audytu [Modern aspects of the formation of the common audit strategy], Visnyk Natsionalnoho universytetu "Lvivska politekhnika", (Bulletin of the National University "Lvivska politekhnika") vol. 797, pp. 269-273. 